\title{
Z nesezdaného soužití do manželství: záleží na vzdělanostní homogamii?'
}

\author{
From Unmarried Cohabitation to Marriage: \\ Does Educational Homogamy Matter?
}

\author{
Dominika Sladká
}

\begin{abstract}
This article examines the association between cohabiting partners' educational homogamy and transition to marriage. This paper enriches previous studies with its comparative dimension to find out if and how the association differs in countries with different meanings of cohabitation - in Austria, Poland, and the Czech Republic. It also examines if and how the association between the transition to marriage and educational homogamy is changing over time. Using data from the first wave of the Generations and Gender Survey (GGS), the analysis shows that the transition to marriage depends on partners' relative education only in countries where cohabitation and marriage are two very different institutions - Poland and the Czech Republic. Educational hypergamy and hypogamy are not associated with the transition in the same way. In cohabitations where the man is more educated, the probability of marriage is half that compared to homogamous cohabitations, whereas cohabitations with a more educated woman are not significantly different from homogamous cohabitations. Over time, the association between relative education and the transition to marriage has not changed.
\end{abstract}

KEYWORDS educational homogamy, unmarried cohabitation, Generations and Gender Survey, transition to marriage

\section{Úvod}

Nesezdaným soužitím neboli kohabitacím se přezdívá různě: manželství na zkoušku, konsensuální svazek i dvoustupňové manželství (Schwartz 2010; Vítečková a Jílková 2011). Většina názvů odkazuje k manželství, které je ve většině zemí považováno za ideální uspořádání, životní úspěch a symbol statusu (Sassler a Lichter 2020). I proto spousta nesezdaných párů dříve nebo později vstoupí do manželství. Načasování manželství i šance, že se nesezdaní partneři žijící pohromadě vůbec vezmou, je závislá na demografických charakteristikách partnerů i na sociálním kontextu (Cherlin 2020). V některých zemích (např. Itálie a Polsko) je výskyt nesezdaných soužití nízký a jejich trvání krátké. Jinde (např. Česko a Mad’arsko)

Sociální studia / Social Studies 1/2021. S. 141-158. ISSN 1214-813X.

1 Tento článek byl finančně podpořen projektem specifického výzkumu na FSS MU, č. MUNI/A/1359/2019. Poděkování za komentáře a konstruktivní kritiku patří prof. Martinu Kreidlovi a dvěma anonymním recenzentům/recenzentkám. 
je život v nesezdaném soužití považovaný za předstupeň manželství. Např́iklad ve Švédsku už ale lidé nesezdaná soužití a manželství téměř nerozlišují (Heuveline a Timberlake 2004; Nazio 2008). V zemích, kde kohabitace nejsou běžné, většina párů vstupuje do manželství (Heuveline a Timberlake 2004). Ve společnostech, kde jsou kohabitace přijatelnou alternativou manželství, je takových párů méně, ale někteří nesezdaní partneři se i tak berou. Formování svazků totiž kromě důvodů normativních, legálních a finančních ovlivňují i faktory afektivní, a právě $\mathrm{v}$ zemích, které jsou v rovnosti kohabitací a manželství nejdále, hrají pozitivní pocity spojené s manželstvím největší roli (Billari a Liefbroer 2016).

Mezi fázemi partnerského vztahu dochází k selektivnímu procesu. Ten je často zmiňován v souvislosti se vzdělanostní homogamií, která označuje situaci, kdy mají oba partneři stejnou úroveň vzdělání. Opakem homogamních svazků jsou svazky heterogamní, v nichž se partneři z hlediska vzdělání liší (Katrňák 2008a). Rozlišují se také partnerství hypogamní a hypergamní. V souladu s většinou studií výběrového párování (např. Esteve et al. 2016; Mäenpää 2015; Qian 2017) je zde používáno označení hypogamie pro vztahy, v nichž je vzdělanější žena, a hypergamie pro ty se vzdělanějším mužem. Vzdělanostní homogamie podle některých studií (Blackwell a Lichter 2000; Hamplová a Le Bourdais 2008; Schwartz 2010) vede k vyšší šanci na manželství. Mäenpää (2015) ale ukázala, že efekt vzdělanostní homogamie není tak jednoznačný.

Tato studie reaguje na nekonzistenci výsledků předchozích studií. Lze předpokládat, že selektivní proces není ve všech zemích stejně výrazný. V zemích, kde jsou kohabitace marginálním fenoménem nebo manželstvím na zkoušku, jsou nesezdaná soužití méně závazným typem vztahu než manželství. Mezi kohabitací a manželstvím proto dochází k selekci (Blackwell a Lichter 2004). Naopak ve společnostech, kde jsou kohabitace přijatelnou dlouhodobou alternativou manželství, záleží výběr z těchto dvou forem vztahu na každém páru (Nazio 2008) a je pravděpodobné, že v nich není tranzice do manželství tolik závislá na charakteristikách páru, mezi něž patří i relativní vzdělání partnerư. ${ }^{2}$ Tento článek se zaměřuje na to, jaký je efekt relativního vzdělání partnerů v nesezdaných soužitích na tranzici do manželství a jak tento efekt závisí na významu nesezdaných soužití v zemi a na tom, kdy kohabitace vznikla. Na základě teorie o významech nesezdaných soužití (Heuveline a Timberlake 2004) a dostupnosti zemí v datech Generations and Gender Survey byly ke zkoumání zvoleny tři evropské země - Rakousko, Polsko a Česko. V následujících sekcích je představeno vzdělanostně výběrové párování $\mathrm{v}$ kohabitacích a manželstvích, teorie vysvětlující rozdíly $\mathrm{v}$ párování v kohabitacích a manželstvích a významy nesezdaných soužití v různých zemích.

\section{Vzdělanostní výběrové párování}

V tom, zda vznikne partnerství vzdělanostně homogamní, hypogamní nebo hypergamní, hrají roli faktory individuální, strukturální a sociální (Katrňák 2008a). Individuální faktory neboli partnerské preference se u mužů a žen liší (Hamplová a Pikálková 2002; Šetinová a Klímová Chaloupková 2019). Zatímco ženy při výběru partnera kladou větší důraz na partnerovo

2 Pojem relativní vzdělání partnerů je v této studii používán v souladu se studií Schwartz a Han (2014) k vyjádření poměru mezi úrovní vzdělání partnerů. 
finanční zajištění a vzdělání, muže více zajímá vzhled potenciálních partnerek. Analýza preferencí Češek a Čechů ucházejících se o studium na vysoké škole ukázala, že finanční situaci považovalo za důležitou $54 \%$ žen a $24 \%$ mužů, vysokoškolské vzdělání pak u svého protějšku pokládalo za důležité 43 \% žen a 37 \% mužů (Šetinová a Klímová Chaloupková 2019). Hamplová a Pikálková (2002: 137) na základě dat z českého šetření Mladá generace 1997, zkoumajícího hodnoty lidí ve věku 18-29 let, zjistily, že „,[̌]]eny prrisuzovaly vyšší význam zejména těm vlastnostem partnera, které souvisejí s celkovým materiálním zajištěním rodiny a s jejím společenským statusem“. Rozdíly v partnerských preferencích podle Zentnera a Eagly (2015) existují kvůli rolím, které jsou ženám a mužům připisovány na základě tradiční genderové specializace v rodinách (např. Becker 1985). S poklesem genderové nerovnosti v zemích ale rozdíly mezi preferencemi mužů a žen klesají (Zentner a Mitura 2012). Patrně kvůli tradiční genderové specializaci v rodinách mohou být vztahy se vzdělanější ženou stále stigmatizované (Van Bavel et al. 2018). Vyšší vzdělání ale vždy neznamená vyšší status. Podle Mäenpää (2015) mohou mít muži ve vzdělanostně hypogamních vztazích výhodu $\mathrm{v}$ jiném měřítku socioekonomického statusu, např́klad v př́ijmu, a vzdělání ženy proto nemusí být pro muže problém. To ostatně ve své analýze potvrdily Chudnovskaya a Kashyap (2020) zjištěním, že ženy, jež mají vyšší vzdělání než jejich partneři, mají i tak nižší př́ijmy než oni. Genderový rozdíl v prŕijmech mužů a žen se sice ve většině evropských zemí snižuje, ale stále existuje (Redmond a Mcguinness 2018).

Nabídka potenciálních partnerů je omezená strukturálními faktory - velikostí a strukturou partnerského trhu. Jako partnerský trh funguje především škola, práce, sociální sítě prátel, volnočasové aktivity a internet (Blossfeld 2009; Potarca 2017). Významnou roli ve formování trhu hraje vzdělávací systém (Blossfeld 2009; Thornton et al. 2007). Lidé, kteří v době hledání partnera ještě studují, si s vyšší pravděpodobností najdou stejně vzdělaného partnera (Blossfeld 2009). Sociální sít je navíc z hlediska budoucího vzdělání tím homogennější, čím člověk ve vzdělávacím systému postupuje výše (Blossfeld 2009; Mare 1991). Vzdělanostní expanze, ke které došlo ve většině vyspělých zemí, proto mohla ovlivnit podíl vzdělanostně homogamních vztahů $\mathrm{v}$ populaci (Mare 1991). Na tento podíl mohl mít vliv i rostoucí věk při uzavření prvního manželství nebo obrácení genderového rozdílu ve vzdělání (Esteve et al. 2016). Vliv strukturálních faktorů na relativní vzdělání partnerů ale nemusí být jednoznačný, protože někteří lidé na partnerský trh dobrovolně nevstupují a volí singlovství (Bellani et al. 2017; Tomášek 2006). Vstup do manželství je navíc v Evropě vzdělanostně stratifikovaný. Zatímco v genderově tradičnějších společnostech má vzdělání žen na vstup do manželství negativní vliv, $v$ egalitárnějších společnostech je tento vliv pozitivní. Vzdělanější muži mají vyšší šanci na manželství než méně vzdělaní (Kalmijn 2013).

Zatímco historicky měli muži vyšší vzdělání než ženy, ve druhé polovině dvacátého století se genderový rozdíl ve vzdělání začal obracet (Esteve et al. 2016). V roce 2009 už podíl žen $\mathrm{v}$ terciárním vzdělávání převyšoval podíl mužů v terciárním vzdělávání téměř ve všech evropských zemích (De Hauw et al. 2017). Genderový rozdíl ve vzdělání je na národní úrovni asociovaný s poklesem vzdělanostní hypergamie a vzrůstem vzdělanostní hypogamie (ibid.). Tyto trendy se objevily i v Česku, Polsku a Rakousku. Ze srovnání kohort 1950-1959, 19601969 a 1970-1979 vyplývá, že v Česku a v Rakousku došlo ke konvergenci podílu hypergamních a hypogamních vztahů (ibid.). Zatímco v nejstarší kohortě v obou zemích převládaly 
vztahy se vzdělanějším mužem, v nejmladší kohortě byl v Česku podíl vzdělanostně hypergamních a hypogamních vztahů téměř vyrovnaný. Také v Rakousku se tyto podíly přibližily, ale na rozdíl od Česka v nejmladší kohortě stále mírně převládaly hypergamní partnerství. V Polsku lze pozorovat jiný trend - už v první kohortě dominovaly hypogamní svazky nad svazky hypergamními a časem se tento nepoměr zvětšil (ibid.).

\section{Trendy ve vzdělanostním výběrovém párování}

Ve většině evropských zemí na začátku 21. století převládala manželství stejně vzdělaných partnerů (Domański a Przybysz 2007; Katrňák 2008b; Katrňák et al. 2006). To platí i pro Rakousko, Polsko a Česko, kterými se zabývá tato studie. V Rakousku v letech 2004-2005 dosahoval podíl vzdělanostně homogamních manželství 54 \%, v Polsku 52 \% a v Česku 76 \% (Domański a Przybysz 2007). Ve zbývajících manželstvích byla vzdělanostní úroveň mužů a žen nestejná. Zatímco v Rakousku a v Česku převládala hypergamní manželství (se vzdělanějším mužem) nad hypogamními (se vzdělanější ženou), v Polsku tomu bylo naopak (ibid.).

Manželství a nesezdaná soužití se z hlediska relativního vzdělání liší. Podle Hamplové (2009) bývají kohabitace homogamnější. Její studie s daty z European Social Survey ale pracovala pouze s přetrvávajícími svazky. Limitem tohoto způsobu práce s kohabitacemi je to, že nebere v úvahu soužití, která vznikla ve stejné době jako ta přetrvávající, ale už se rozpadla. Kohabitace, které mají vyšší tendenci se rozpadat, pak v analýze nejsou reprezentativně zastoupeny. Schwartz (2010) oproti tomu analyzovala všechny vzniklé svazky i odchody z nich. Zjistila, že kohabitace v USA jsou častěji vzdělanostně heterogamní než manželství. K podobným výsledkům došli i Blackwell a Lichter (2000) nebo Hamplová a Le Bourdais (2008).

Důvodů, proč bývají nesezdaná soužití častěji vzdělanostně heterogamní než manželství, může být několik. Jedním z nich jsou odlišnosti manželských a kohabitujících párů. Lidé žijící v nesezdaném soužití mají v porovnání s ženatými/vdanými méně tradiční postoje menší podíl kohabitujících souhlasí s tím, že předškolní dítě trpí bez matky, a má nesouhlasný postoj k tomu, když chce žena vychovávat dítě sama (Kreidl 2010). Kohabitující páry oproti manželským párům méně často spojují své peníze (Hamplová 2015) a mají rovnější dělbu práce v domácnosti (Domínguez-Folgueras 2013; Klímová Chaloupková 2018). Výběr partnera do kohabitace má navíc volnější pravidla kvưli tomu, že kohabitace je méně závazná než manželství (Schwartz 2010).

Alternativní vysvětlení vyšší homogamie v manželství vychází z perspektivy dvojité selekce, podle které si lidé partnera vybírají dvakrát - poprvé při vstupu do kohabitace a podruhé při uzavření manželství (Blackwell a Lichter 2004; Mäenpää 2015). Kohabitace jsou z této perspektivy manželstvím na zkoušku, které umožňuje ohodnocení potenciálu vztahu před sňatkem (Blossfeld 2009; Schwartz 2010). Vyšší vzdělanostní heterogamie $\mathrm{v}$ nesezdaných soužitích je podle této teorie způsobena tím, že vzdělanostně homogamní kohabitace častěji než vzdělanostně heterogamní vedou k manželství a heterogamní kohabitace se častěji rozpadají (Schwartz 2010). Z perspektivy kulturní shody je tento jev vysvětlovaný tím, že lidé preferují jedince s podobnými hodnotami, postoji a životním stylem, a jelikož manželství je chápáno jako větší závazek, je v něm tato preference silnější (Mäenpää 2015; Schwartz 2010). 
Schwartz (2010) hypotézu předpokládající vyšší šanci homogamních kohabitací na manželství svou analýzou amerických dat podpořila. Mäenpää (2015) na finských datech ukázala, že vliv vzdělanostní homogamie kohabitací na přechod do manželství závisí na absolutním vzdělání partnerů - u lidí se základním vzděláním homogamie šanci na manželství zvyšuje a u vysokoškolsky vzdělaných ji snižuje. Důvodem odlišných výsledků mohou být odlišné významy kohabitací. Podle dynamického scénáře (Hamplová 2009) se rozdíly ve výběrovém párování nesezdaných soužití a manželství liší podle toho, jaká je funkce nesezdaných soužití v dané společnosti. Tam, kde jsou nesezdaná soužití nerozeznatelná od manželských svazků, by neměly být rozdíly mezi nimi významné.

Šance vzdělanostně heterogamních nesezdaných soužití na manželství se může lišit i podle toho, zda má vyšší vzdělání žena, nebo muž. Muži v nepř́íznivé ekonomické situaci vstupují častěji do nesezdaných soužití než do manželství (Kalmijn 2011). Kohabitace jsou totiž méně závazné než manželství a nesezdaní partneři většinou nemají tolik společných investic (Hamplová 2002). Nesezdaná soužití, ve kterých má vy̌šśi vzdělání muž, by proto mohla častěji vést $\mathrm{k}$ manželství. Na druhou stranu to, že jeden z partnerů touží po manželství, neznamená, že tomu tak bude. V partnerských vztazích dochází k vyjednávání, při němž záleží na poměru moci vyplývajícím i ze socioekonomického statusu partnerů (Chudnovskaya a Kashyap 2020). Partner, který má vyšší vzdělání nebo prŕijem, může mít také vyšší moc, protože je pro něj snazší ze vztahu odejít. Teorie sociální směny totiž říká, že přetrvávání lidí ve vztazích záleží na atraktivitě vztahu, bariérách, které jim brání v odchodu, a na alternativách současného vztahu (Levinger 1976). Pro člověka s vy̌̌ším vzděláním nebo př́ijmy může být snazší se $\mathrm{s}$ partnerem rozejít, jelikož mu v rozchodu nebrání tolik bariér a má více alternativ (Kreager et al. 2013; Levinger 1976). Je proto pravděpodobné, že při rozdílných manželských intencích partnerů se vyplní přání toho, kdo má vyšší status.

V článku je ověřována je teorie dvojité selekce, podle níž jsou nesezdaná soužití manželstvím na zkoušku sloužícím k dodatečné selekci partnerů, a teorie kulturní shody, podle které lidé v manželství jakožto dlouhodobém svazku preferují stejně vzdělané jedince (Blackwell a Lichter 2004; Mäenpää 2015; Schwartz 2010). První hypotéza předpokládá, že vzdělanostně homogamní nesezdaná soužití mají vyšší riziko tranzice do manželství než vzdělanostně heterogamní nesezdaná soužití (hypotéza 1). Je možné, že i heterogamní kohabitace se $\mathrm{v}$ tranzici do manželství liší podle toho, který z partnerů má vyšší vzdělání. Jak ukázaly analýzy partnerských preferencí (Hamplová a Pikálková 2002; Šetinová a Klímová Chaloupková 2019), vzdělání u svých protějšků považují za důležitějš́ ženy než muži. Proto další hypotéza předpokládá, že vzdělanostně hypergamní nesezdaná soužití mají vyšší riziko tranzice do manželství než vzdělanostně hypogamní nesezdaná soužití (hypotéza 2).

Ačkoliv lze předpokládat, že se kohabitace na základě relativního vzdělání partnerů $\mathrm{v}$ šanci na manželství liší, rozdíly mezi nimi nemusí být např́íc zeměmi stejné. V různých zemích totiž lidé nesezdaným soužitím přikládají různé významy, a proto se i selektivní proces při tranzici z nesezdaného soužití do manželství může lišit. Ve studii je ověřován předpoklad, že teorie dvojité selekce silněji platí tam, kde je výskyt kohabitací nižší a kde jsou kohabitace a manželství odlišnými svazky. Různé významy nesezdaných soužití a z nich vycházející hypotézy představuje následující část. 


\section{Významy nesezdaných soužití}

Heuveline a Timberlake (2004) rozdělují země do šesti kategorií podle toho, jaký ideální typ nesezdaného soužití v nich převládá - marginální, předstupeň manželství, fáze v manželském procesu, alternativa single života, alternativa manželství a nerozeznatelné od manželství. ${ }^{3}$ Některé autorky (Kiernan 2002; Nazio 2008) místo typů nesezdaných soužití rozlišují fáze, v nichž se země z hlediska výskytu a funkce kohabitací nacházejí. Nazio (2008) hovoří o difúzním procesu, při kterém se kohabitace rozšířily nejdříve na severu Evropy a poté se šírily směrem na jih. V první fázi procesu jsou nesezdaná soužití něčím výjimečným, co se týká jen vybrané skupiny lidí, která má o život v kohabitaci osobní zájem. Ve druhé fázi jsou nesezdaná soužití krokem před uzavřením sňatku, ale rodí se v nich i poměrně velké množství dětí. Ve třetí fázi jsou kohabitace téměř nerozeznatelné od manželství, a volba mezi kohabitací a manželstvím záleží jen na preferencích konkrétního páru (Heuveline a Timberlake 2004; Nazio 2008). Nazio (2008) tvrdí, že čím nižší je výskyt nesezdaných soužití v zemi, tím méně je takové soužití výhodné. V zemích s nízkým výskytem kohabitací k nim tíhnou jen ti, kteří mají pro založení kohabitace osobní důvody - např́iklad touha po méně závazné formě soužití, strach z neúspěšného manželství, ideologické odmítání manželství nebo ekonomické důvody (ibid.). Čím jsou nesezdaná soužití v zemi institucionalizovanější a běžnější, tím méně jsou pro kohabitaci podstatné osobní zájmy a za výhodné je začnou pokládat i ostatní (ibid.). Di Giulio a Rosina (2007) ale upozorňují, že na difúzi kohabitací mají vliv sociální a kulturní faktory, postoje mladých dospělých a jejich rodičů, ale i politiky zemí. Proto je možné, že ne všechny evropské země dojdou až do bodu, kdy budou kohabitace a manželství téměř nerozeznatelné (Di Giulio et al. 2019).

V této studii jsou analyzována data z Rakouska, Polska a Česka. Nejnižší výskyt nesezdaných soužití je v Polsku, kde jsou podle Heuvelina a Timberlaka (2004) kohabitace marginálním fenoménem. V Polsku žije v kohabitacích malé množství lidí - v letech 20122013 jich bylo necelých 5 \% (Reznik 2014). Po krátké době v nesezdaném soužití většinou následuje vstup do manželství a v nesezdaných soužitích se nerodí mnoho dětí (Heuveline a Timberlake 2004). Přesto Polsko není vůči šíření kohabitací imunní a na začátku 21. století vstoupilo do druhé fáze difúzního procesu (Matysiak 2009; Mynarska a Matysiak 2010). Nesezdaná soužití se v Polsku stávají běžnější formou partnerství a dostávají se i mezi vzdělanější obyvatele, ale stále jsou nejčastější mezi těmi nejméně vzdělanými (Mynarska a Matysiak 2010). Na kohabitace sice mladí Poláci nahlížejí pozitivně, ale jen pokud slouží jako předmanželské uspořádání (Mynarska a Bernardi 2007). Manželství si na rozdíl od kohabitace spojují se závazkem a narození dítěte mimo manželství většinou vidí jako problém (ibid.).

V Česku je podíl nesezdaných soužití o něco vyšší než v Polsku a podle Heuvelina a Timberlaka (2004) slouží z většiny jako předstupeň manželství. V letech 2012-2013 v nich v Česku žilo přes 11 \% lidí (Reznik 2014). Kohabitace je v českém prostředí „,akceptovatelnou součástí procesu námluv, zaplňuje v životní dráze lidí čas před vstupem do manželství,“

Jako indikátory ideálních typů používají podíl kohabitujících párů s dítětem, délku vystavení dítěte kohabitaci, podíl nesezdaných párů s dítětem, které přejdou do manželství, výskyt kohabitací, jejich průměrné trvání a podíl kohabitací ukončených uzavřením sňatku. 
vysvětlují Kreidl a Štípková (2012: 134). Pro téměř tři čtvrtiny Čechů narozených v 70. letech minulého století bylo prvním koresidenčním svazkem nesezdané soužití a pro mladší generace je tato forma rodinného uspořádání ještě běžnější (Št’astná a Paloncyová 2011). Děti se do nesezdaných soužití rodí poměrně často, ale téměř $40 \%$ nesezdaných párů s dítětem vstoupí do manželství (Chaloupková 2011).

Podobným typem jako předstupeň manželství je fáze $\mathrm{v}$ manželském procesu, která převládá v Rakousku. Od předstupně manželství se tento typ liší především v tom, že se v něm rodí ještě větší množství dětí. Pro páry v tomto typu nesezdaného soužití je typické, že počítají s tím, že vstoupí do manželství, ale prozatím ho odsouvají (Heuveline a Timberlake 2004). Kohabitaci Rakušané a Rakušanky chápou jako nejvhodnější uspořádání v období mladé dospělosti a manželství je pro ně znakem vyspělosti a stability, a proto $\mathrm{k}$ němu častěji přistupují až v pozdější fázi života (Berghammer et al. 2014; Perelli-Harris a Bernardi 2015).

V článku je analýzou tř́ zmíněných zemí - Rakouska, Polska a Česka - ověrována teorie dvojité selekce (Blackwell a Lichter 2004) ve spojení s difúzí nesezdaných soužití (Nazio 2008). Teorie difúze předpokládá, že čím více se nesezdaná soužití v zemi šírí, tím více se podobají manželství, a čím více se tyto dva svazky podobají, tím méně jsou pro výběr mezi nimi důležité charakteristiky partnerů. Proto se na základě teorie difúze lze domnívat, že čím dále je země v šiření kohabitací, tím méně je pro přechod do manželství důležité relativní vzdělání partnerů. Jelikož Rakousko je ze tří analyzovaných zemí v difúzi kohabitace nejdále, je v článku ověřována hypotéza, že asociace mezi relativním vzděláním partnerů a rizikem tranzice do manželství je nejslabší v Rakousku (hypotéza 3). V souladu s teorií difúzního procesu je pravděpodobné, že asociace mezi relativním vzděláním partnerů a rizikem tranzice do manželství je slabší u těch soužití, která vznikla později (hypotéza 4).

\section{Data a metody}

\section{Data}

V analýze byly použity partnerské historie z první vlny výzkumu Generations and Gender Survey (GGS) (Generations and Gender Programme 2019). GGS sestává z národně reprezentativních, snadno srovnatelných výběrových šetření neinstitucionalizované populace ve věku 18 až 79 let (Vikat et al. 2007). Protože východiskem studie je typologie nesezdaných soužití Heuvelina a Timberlaka (2004), k analýze byly vybrány země, kterými se stat’ těchto autorů zabývá a které jsou zároveň dostupné v první vlně dat z GGS. Data z první vlny byla použita proto, že ve většině zemí na rozdíl od dat z druhé vlny obsahují vzdělání partnerů respondentů. Země, které informaci o vzdělání partnerů neobsahovaly, v analýze nebyly použity. Po uvážení těchto podmínek byly vybrány tři země: Rakousko, Polsko a Česko. V Rakousku se sběr dat konal v letech 2008-2009, v Polsku v letech 2010-2011 a v Česku v roce 2005 (Gauthier et al. 2018).

V analýze byla zahrnuta všechna nesezdaná soužití respondentů. Každý měl možnost uvést až devět partnerství v partnerské historii a kromě toho i partnerství současné. Soubor byl omezen pouze na heterosexuální vztahy respondentů do věku 45 let. Před analýzou byla data upravena tak, aby každé koresidenční partnerství respondenta tvořilo jeden př́ípad. $\mathrm{Z}$ analytického souboru byla odstraněna partnerství, v nichž partneři vstoupili do manželství 
ve stejném měsíci, kdy spolu začali žít, případně uvedli datum sňatku přecházející datu začátku společného bydlení (6 276). Dále byly smazány př́ípady, u nichž bylo neznámé vzdělání respondenta nebo jeho partnera (773). Byla vyloučena nesezdaná soužití vzniklá před osmnáctým rokem života respondenta (427). Dále byla odstraněna soužití, na jejichž konci měl respondent nižší vzdělání než v době sběru dat (779). Data totiž neobsahují informace o vzdělání respondenta $\mathrm{v}$ době jednotlivých kohabitací, ale obsahují měsíc a rok, ve kterém respondent dosáhl nejvyššího vzdělání. Redukovaný analytický soubor obsahoval 6660 př́padů. Respondentů v souboru bylo 5895 . Z nich 5233 mělo v souboru jen jedno nesezdané soužití a 662 respondentů jich mělo více (dvě soužití -571 respondentů, tři soužití -81 respondentů, čtyři soužití -9 respondentů, šest soužití -1 respondent).

\section{Metody a proměnné}

Pro práci s daty byla zvolena analýza historie událostí, která umožňuje „sledovat časování základních životních událostí a studovat faktory, které výskyt daných událostí ovlivňují. Činí tak prostřednictvím výpočtu rizika, že u jedince nastane sledovaná událost“" (Štastná 2011: 60). Konkrétně byla zvolena Coxova regrese, kterou lze použít i pro analýzu dat, v nichž je čas měřen jako diskrétní proměnná - $\mathrm{v}$ datech $\mathrm{z}$ GGS jsou události měřeny s přesností na měsíc. Coxova regrese modeluje hazard, který lze interpretovat jako riziko události v čase $t$ (Walters 2012). Metoda předpokládá tzv. proporční hazard - to znamená, že jestliže má jedna skupina respondentů dvakrát vyšší riziko události než jiná skupina, bude mít toto riziko dvakrát větší v každém časovém bodě (ibid.)

Analyzovanou událostí byla tranzice do manželství. Čas byl v regresi měřený jako počet měsíců mezi začátkem nesezdaného soužití a jeho rozpadem, vstupem do manželství nebo prvním rozhovorem (podle toho, která z těchto událostí nastala nejdř́ve). Nesezdaná soužití, která trvala ještě v době rozhovoru a u nichž nedošlo k tranzici do manželství, byla cenzorována zprava. Coxova regrese nedovoluje pracovat s př́pady, které vstoupily do a vystoupily $z$ rizikové skupiny (tzn. nesezdaného soužití) ve stejném čase. Pokud tento př́ípad nastane, je potřeba mezi vstup a výstup z rizikové skupiny vložit krátký časový úsek (StataCorp 2013: 498-499). Jelikož ve čtyřech př́padech tato situace nastala, u všech př́padů bylo v proměnné značící začátek vystavení riziku odečteno 0,01 . Jelikož 10 \% respondentů je v souboru více než jednou, byla použita Coxova regrese s robustními standardními chybami upravenými pro shlukovou strukturu dat. Modely byly porovnávány pomocí Waldova testu a Akaikova informačního kritéria (AIC). Data byla analyzována prostřednictvím softwaru STATA (StataCorp 2019).

Data obsahovala proměnné nejvyšší dosažené vzdělání respondenta a nejvyšší dosažené vzdělání jeho partnera, z nichž byly vytvořeny proměnné vzdělání ženy a vzdělání muže. Tyto proměnné byly překódovány do tř́ kategorií - maximálně nižší sekundární (ISCED 0,1,2), sekundární nebo postsekundární neterciární (ISCED 3, 4) a terciární (ISCED 5, 6). Kombinací vzdělání muže a vzdělání ženy vznikla proměnná relativní vzdělání se třemi kategoriemi - homogamie, hypogamie a hypergamie. Proměnné absolutní vzdělání muže a absolutní vzdělání ženy byly do analýzy zařazeny jako kontrolní proměnné. Dalšími kontrolními proměnnými bylo pohlaví respondenta, věk při začátku nesezdaného soužití a rok začátku 
nesezdaného soužití (v části analýzy byl rok začátku nesezdaného soužití používán v interakci s hypergamií a hypogamií k otestování toho, zda se asociace relativního vzdělání a tranzice do manželství v čase měnila).

\section{Výsledky}

Tabulka 1 znázorňuje podíly vzdělanostně homogamních, hypergamních, a hypogamních kohabitací. Ve všech třech zemích převládají homogamní soužití - v Rakousku jich je 66,7 \%, v Polsku 69,1 \% a v Česku 73,7 \%. V Rakousku a Česku jsou druhým nejčastějším soužitím ta hypergamní. V Polsku naopak podíl hypogamních soužití převládá nad hypergamními. Distribuci kontrolních proměnných ukazuje tabulka 2.

Tabulka 1: Nesezdaná soužití podle relativního vzdělání a zemí. GGS 1. Nesezdaná soužití respondentů do 45 let. $\mathrm{N}=6660$

\begin{tabular}{|l|c|c|c|c|}
\hline $\begin{array}{l}\text { Relativní vzdělání } \\
\text { partneru }\end{array}$ & Rakousko & Polsko & Česko & Celkem \\
\hline Homogamie & $66,7 \%(1999)$ & $69,1 \%(1416)$ & $73,7 \%(1189)$ & $69,1 \%(4604)$ \\
\hline Hypergamie & $21,5 \%(644)$ & $11,5 \%(236)$ & $14,5 \%(234)$ & $16,7 \%(1114)$ \\
\hline Hypogamie & $11,8 \%(354)$ & $19,4 \%(397)$ & $11,8 \%(191)$ & $14,1 \%(942)$ \\
\hline Celkem & $100 \%(2997)$ & $100 \%(2049)$ & $100 \%(1614)$ & $100 \%(6660)$ \\
\hline
\end{tabular}

Tabulka 2: Distribuce kontrolních proměnných v jednotlivých zemích. GGS 1. Nesezdaná soužití respondentů do 45 let. $\mathrm{N}=6660$

\begin{tabular}{|l|c|c|c|c|}
\hline $\begin{array}{l}\text { Kontrolní } \\
\text { proménné }\end{array}$ & Rakousko & Polsko & Česko & Celkem \\
\hline Pohlaví & & & & \\
\hline Muž & $38,8 \%(1162)$ & $45,4 \%(930)$ & $46,4 \%(749)$ & $42,7 \%(2841)$ \\
\hline Žena & $61,2 \%(1835)$ & $54,6 \%(1119)$ & $53,6 \%(865)$ & $57,3 \%(3819)$ \\
\hline $\begin{array}{l}\text { Věk při začátku } \\
\text { kohabitace }\end{array}$ & & & & \\
\hline $18-26$ & $69,3 \%(2076)$ & $68,4 \%(1402)$ & $71,0 \%(1145)$ & $69,4 \%(4623)$ \\
\hline $27-34$ & $24,6 \%(736)$ & $27,3 \%(559)$ & $22,6 \%(365)$ & $24,9 \%(1660)$ \\
\hline $35-45$ & $6,2 \%(185)$ & $4,3 \%(88)$ & $6,4 \%(104)$ & $5,7 \%(377)$ \\
\hline $\begin{array}{l}\text { Rok začátku } \\
\text { kohabitace }\end{array}$ & $13,2 \%(395)$ & $2,6 \%(54)$ & $14,8 \%(239)$ & $10,3 \%(688)$ \\
\hline $1978-1989$ & $56,9 \%(1705)$ & $34,4 \%(704)$ & $64,3 \%(1038)$ & $51,8 \%(3447)$ \\
\hline $1990-2002$ & $29,9 \%(897)$ & $63,0 \%(1291)$ & $20,9 \%(337)$ & $37,9 \%(2525)$ \\
\hline $2003-2011$ & $100 \%(2997)$ & $100 \%(2049)$ & $100 \%(1614)$ & $100 \%(6660)$ \\
\hline Celkem & & &
\end{tabular}


V tabulce 3 jsou rozlišené tranzice kohabitací podle relativního vzdělání partnerů. Z celkového vzorku 6660 nesezdaných soužití (poslední řádek tabulky) více než polovina vstoupila do manželství. Téměř třetina zkoumaných svazků zůstala nesezdanými soužitími až do prvního rozhovoru. Zbytek kohabitací (18,5 \%) se rozpadl, a to bud' rozchodem, úmrtím jednoho z partnerů, nebo ukončením společného bydlení. Nejvíce nesezdaných soužití změněných v manželství bylo v Polsku, kde do manželství vstoupily necelé dvě třetiny soužití. V Česku i Rakousku se tento podíl pohyboval okolo 50 \%. V Rakousku nejčastěji vstupovaly do manželství kohabitace, v nichž měl vyšší vzdělání muž (54,8 \%). V Polsku do manželství nejčastěji vstupovaly páry se vzdělanější ženou (59,5 \%) a v Česku do manželství nejčastěji vstupovaly vzdělanostně homogamní páry (53\%).

Tabulka 3: Tranzice nesezdaných soužití podle relativního vzdělání partnerů a zemí. GGS 1. Nesezdaná soužití respondentů do 45 let. $\mathrm{N}=6660$

\begin{tabular}{|l|l|c|c|c|c|}
\hline \multirow{2}{*}{ Země } & $\begin{array}{l}\text { Relativní vzdělání } \\
\text { partnerú }\end{array}$ & Manželství & $\begin{array}{c}\text { Rozpad } \\
\text { kohabitace }\end{array}$ & $\begin{array}{c}\text { Stále } \\
\text { v kohabitaci }\end{array}$ & Celkem \\
\hline \multirow{2}{*}{ Rakousko } & Homogamie & $48,1 \%(962)$ & $23,3 \%(465)$ & $28,6 \%(572)$ & $100 \%(1999)$ \\
\cline { 2 - 6 } & Hypergamie & $54,8 \%(353)$ & $20,8 \%(134)$ & $24,4 \%(157)$ & $100 \%(644)$ \\
\cline { 2 - 6 } & Hypogamie & $45,2 \%(160)$ & $28,0 \%(99)$ & $26,8 \%(95)$ & $100 \%(354)$ \\
\cline { 2 - 6 } & Celkem & $49,2 \%(1475)$ & $23,3 \%(698)$ & $27,5 \%(824)$ & $100 \%(2997)$ \\
\hline \multirow{3}{*}{ Polsko } & Homogamie & $57,3 \%(812)$ & $14,0 \%(198)$ & $28,7 \%(406)$ & $100 \%(1416)$ \\
\cline { 2 - 6 } & Hypergamie & $47,5 \%(112)$ & $21,6 \%(51)$ & $30,9 \%(73)$ & $100 \%(236)$ \\
\cline { 2 - 6 } & Hypogamie & $59,5 \%(236)$ & $13,1 \%(52)$ & $27,5 \%(109)$ & $100 \%(397)$ \\
\cline { 2 - 6 } & Celkem & $56,6 \%(1160)$ & $14,7 \%(301)$ & $28,7 \%(588)$ & $100 \%(2049)$ \\
\hline \multirow{5}{*}{ Česko } & Homogamie & $53,0 \%(630)$ & $13,1 \%(156)$ & $33,9 \%(403)$ & $100 \%(1189)$ \\
\cline { 2 - 6 } & Hypergamie & $40,6 \%(95)$ & $21,4 \%(50)$ & $38,0 \%(89)$ & $100 \%(234)$ \\
\cline { 2 - 6 } & Hypogamie & $45,0 \%(86)$ & $13,1 \%(25)$ & $41,9 \%(80)$ & $100 \%(191)$ \\
\cline { 2 - 6 } & Celkem & $50,3 \%(811)$ & $14,3 \%(231)$ & $35,4 \%(572)$ & $100 \%(1614)$ \\
\hline
\end{tabular}

Tabulka 4 prezentuje tři modely Coxovy regrese. Model 1 obsahuje proměnné vzdělání muže a vzdělání ženy, pohlaví, věk respondenta při začátku kohabitace, rok začátku kohabitace a zemi. Model 2 kromě nich zahrnuje i relativní vzdělání partnerů se třemi kategoriemi. Model 3 obsahuje stejné proměnné jako Model 2 a kromě nich i interakci mezi relativním vzděláním a zeměmi.

V Modelu 1 lze vidět poměry rizik jednotlivých vzdělanostních kategorií mužů a žen bez kontroly relativního vzdělání. Muži ani ženy se podle vzdělání v riziku vstupu do manželství významně neliší. Kontrolní proměnné s výjimkou pohlaví respondenta jsou s manželstvím významně asociované. Se zvyšujícím se věkem při začátku kohabitace riziko manželství klesá. Tranzice do manželství je závislá i na tom, ve kterém roce soužití vzniklo, přičemž pozdější vznik znamená nižší riziko manželství. Silný efekt na riziko vstupu do manželství 
má i země, ve které respondent žije. Ve srovnání s Rakouskem mají nesezdaná soužití v Polsku o 84 \% vyšší riziko manželství a soužití v Česku mají toto riziko vyšší o 47 \%.

Tabulka 4: Odhadnuté parametry (a standardní chyby) Coxovy regrese s robustními standardními chybami upravenými pro shlukovou strukturu dat pro vstup nesezdaných soužití do manželství. GGS 1 . Nesezdaná soužití respondentů do 45 let. $\mathrm{N}=6660$

\begin{tabular}{|c|c|c|c|}
\hline & Model 1 & Model 2 & Model 3 \\
\hline \multicolumn{4}{|l|}{ Relativní vzdělání (homogamie) } \\
\hline Hypergamie & & $0,64(0,15)+$ & $0,85(0,20)$ \\
\hline Hypogamie & & $1,40(0,33)$ & $1,39(0,34)$ \\
\hline \multicolumn{4}{|l|}{$\begin{array}{l}\text { Vzdělání muže (max. nižší } \\
\text { sekundární) }\end{array}$} \\
\hline $\begin{array}{l}\text { Vyšší sekundární a postsekundární } \\
\text { neterciární }\end{array}$ & $0,95(0,07)$ & $1,35(0,31)$ & $1,26(0,27)$ \\
\hline Terciární & $0,98(0,08)$ & $2,05(0,92)$ & $1,79(0,76)$ \\
\hline \multicolumn{4}{|l|}{$\begin{array}{l}\text { Vzdělání ženy (max. nižší } \\
\text { sekundární) }\end{array}$} \\
\hline $\begin{array}{l}\text { Vyšší sekundární a postsekundární } \\
\text { neterciární }\end{array}$ & $1,06(0,07)$ & $0,72(0,16)$ & $0,72(0,16)$ \\
\hline Terciární & $1,07(0,08)$ & $0,50(0,22)$ & $0,55(0,23)$ \\
\hline \multicolumn{4}{|l|}{ Pohlaví (muž) } \\
\hline Žena & $1,00(0,04)$ & $1,00(0,04)$ & $0,99(0,03)$ \\
\hline \multicolumn{4}{|l|}{$\begin{array}{l}\text { Věk při začátku kohabitace } \\
(18-26)\end{array}$} \\
\hline $27-34$ & $0,88(0,04)^{* *}$ & $0,89(0,04)^{* *}$ & $0,88(0,04)^{* *}$ \\
\hline $35-45$ & $0,63(0,07)^{* * *}$ & $0,64(0,07)^{* * *}$ & $0,57(0,06)^{* * *}$ \\
\hline \multicolumn{4}{|l|}{$\begin{array}{l}\text { Rok začátku kohabitace } \\
\text { (1978-1989) }\end{array}$} \\
\hline 1990-2002 & $0,64(0,04)^{* * *}$ & $0,65(0,04)^{* * *}$ & $0,58(0,03)^{* * *}$ \\
\hline $2003-2011$ & $0,51(0,03)^{* * *}$ & $0,51(0,03)^{* * *}$ & $0,23(0,01)^{* * *}$ \\
\hline \multicolumn{4}{|l|}{ Země (Rakousko) } \\
\hline Polsko & $1,84(0,08)^{* * *}$ & $1,84(0,08)^{* * *}$ & $1,95(0,10)^{* * *}$ \\
\hline Česko & $1,47(0,07)^{* * *}$ & $1,47(0,07)^{* * *}$ & $1,68(0,09)^{* * *}$ \\
\hline \multicolumn{4}{|l|}{ Interakce } \\
\hline Polsko * hypergamie & & & $0,70(0,08)^{* *}$ \\
\hline Polsko * hypogamie & & & $0,99(0,11)$ \\
\hline Česko * hypergamie & & & $0,54(0,08)^{* * *}$ \\
\hline Česko ${ }^{*}$ hypogamie & & & $0,74(0,11) *$ \\
\hline $\mathrm{AIC}$ & 55159,43 & 55157,49 & 55134,06 \\
\hline
\end{tabular}

Pozn.: ***p $\leq 0,001 * * \mathrm{p} \leq 0,010 * \mathrm{p} \leq 0,050+\mathrm{p} \leq 0,1$. 
Model 2 ukazuje poměry rizik pro relativní vzdělání partnerů v nesezdaném soužití. Poměry rizik hypergamie a hypogamie jsou statisticky nevýznamné na hladině významnosti 0,05 a pouze hypergamie, která riziko manželství redukuje o $36 \%$, je významná na hladině 0,1. Model 2 má oproti Modelu 1 nižší AIC, ale výsledek Waldova testu není signifikantní na hladině významnosti 0,05 . Na úrovni všech tří zemí tedy vzdělanostní heterogamie není významně asociovaná s rizikem tranzice do manželství.

Model 3 má ve srovnání s Modelem 2 výrazněji nižší AIC a výsledek Waldova testu signifikantní na hladině významnosti 0,001 ukazuje, že efekty proměnných, které jsou v Modelu 3 navíc, nejsou rovné nule. Poměry rizik homogamie, hypergamie a hypogamie se tedy významně liší. Z tabulky 4 lze vyčíst, že poměry rizik hypergamie a hypogamie jsou v Rakousku, které je referenční zemí, 0,85 a 1,39. Pro výpočet poměrů rizik v Polsku a v Česku je třeba hlavní efekty relativního vzdělání vynásobit př́íslušnými interakcemi. Vypočtené efekty ukazuje tabulka 5.

Tabulka 5: Poměry rizik nesezdaných soužití podle relativního vzdělání partnerů. GGS 1. Nesezdaná soužití respondentů do 45 let. $\mathrm{N}=6660$

\begin{tabular}{|l|l|l|l|}
\hline & Rakousko & Polsko & Česko \\
\hline Homogamie & 1,00 & 1,00 & 1,00 \\
\hline Hypergamie & 0,85 & $0,60^{*}$ & $0,46^{* *}$ \\
\hline Hypogamie & 1,39 & 1,38 & 1,03 \\
\hline
\end{tabular}

Pozn.: ***p $\leq 0,001 * * \mathrm{p} \leq 0,010 * \mathrm{p} \leq 0,050+\mathrm{p} \leq 0,1$.

Z výsledků v tabulce 5 vyplývá, že hypergamie redukuje riziko manželství ve všech zemích, ale v Rakousku je rozdíl statisticky nevýznamný na hladině 0,1 . V Polsku mají hypergamní soužití o 40 \% nižší riziko $(\mathrm{p}<0,05)$ než homogamní. V Česku mají hypergamní soužití o 54 \% nižší riziko než homogamní $(\mathrm{p}<0,01)$. Hypogamie není v žádné zemi s rizikem manželství asociovaná na hladině významnosti 0,1 . Rozdíl v riziku hypogamních a hypergamních kohabitací lze vypočítat vydělením údajů z třetího řádku tabulky 5 údaji z druhého řádku. Jejich statistická významnost byla ověřena v softwaru Stata. V Rakousku se riziko manželství v kohabitacích se vzdělanější ženou a v kohabitacích se vzdělanějším mužem neliší na hladině významnosti 0,1 . V Polsku i v Česku je rozdíl mezi rizikem hypogamních a hypergamních kohabitací významný na hladině 0,1 . V Polsku mají hypogamní kohabitace o 130 \% vyšší riziko tranzice. V Česku mají hypogamní soužití o 124 \% vyšší riziko než soužití hypergamní.

Další část analýzy byla zaměřena na to, zda je rozdíl v rizicích hypergamních a hypogamních kohabitací závislý na době jejich vzniku. Výsledky ukazuje Model 4 v tabulce 6. Tabulka 7 ukazuje efekty hypergamie a hypogamie v různých obdobích vypočítané vynásobením hlavních efektů a příslušných interakcí z Modelu 4. Poměry rizik hypergamních a hypogamních soužití v porovnání $\mathrm{s}$ těmi homogamními se v čase př́lišs nezměnily. Kohabitace se vzdělanějším mužem měly vždy nižší riziko než kohabitace stejně vzdělaných partnerů v prvním období o $31 \%(\mathrm{p}>0,1)$, ve druhém období o $37 \%(\mathrm{p}<0,1)$ a ve třetím období také o $37 \%(p<0,1)$. Kohabitace se vzdělanější ženou a méně vzdělaným mužem měly naopak ve 
všech obdobích vyšší riziko než kohabitace stejně vzdělaných partnerů - v prvním období o $71 \%(\mathrm{p}<0,05)$, ve druhém období o $15 \%(\mathrm{p}>0,1)$ a ve třetím období o $66 \%(\mathrm{p}<0,05)$.

Tabulka 6: Odhadnuté parametry (a standardní chyby) Coxovy regrese s robustními standardními chybami upravenými pro shlukovou strukturu dat pro vstup nesezdaných soužití do manželství. GGS 1. Nesezdaná soužití respondentů do 45 let. $\mathrm{N}=6660$

\begin{tabular}{|c|c|}
\hline & Model 4 \\
\hline \multicolumn{2}{|l|}{ Relativní vzdělání (homogamie) } \\
\hline Hypergamie & $0,69(0,18)$ \\
\hline Hypogamie & $1,71(0,47)^{* *}$ \\
\hline \multicolumn{2}{|l|}{ Vzdělání muže (max. nižší sekundární) } \\
\hline Vyšší sekundární a postsekundární neterciární & $1,31(0,88)$ \\
\hline Terciární & $1,96(0,88)$ \\
\hline \multicolumn{2}{|l|}{ Vzdělání ženy (max. nižší sekundární) } \\
\hline Vyšší sekundární a postsekundární neterciární & $0,73(0,17)$ \\
\hline Terciární & $0,52(0,23)$ \\
\hline \multicolumn{2}{|l|}{ Pohlaví (muž) } \\
\hline Žena & $1,00(0,04)$ \\
\hline \multicolumn{2}{|l|}{ Věk při začátku kohabiłace (18-26) } \\
\hline $27-34$ & $0,89(0,04)^{* *}$ \\
\hline $35-45$ & $0,64(0,07)^{* * *}$ \\
\hline \multicolumn{2}{|l|}{ Rok začátku kohabitace (1978-1989) } \\
\hline 1990-2002 & $0,69(0,04)^{* * *}$ \\
\hline 2003-2011 & $0,51(0,04)^{* * *}$ \\
\hline \multicolumn{2}{|l|}{ Země (Rakousko) } \\
\hline Polsko & $1,84(0,08) * * *$ \\
\hline Česko & $1,47(0,07)^{* * *}$ \\
\hline \multicolumn{2}{|l|}{ Interakce } \\
\hline 1990-2002* hypergamie & $0,92(0,13)$ \\
\hline 1990-2002* hypogamie & $0,67(0,11)$ \\
\hline 2003-2011 * hypergamie & $0,91(0,15) *$ \\
\hline 2003-2011 * hypogamie & $0,97(0,16)$ \\
\hline $\mathrm{AIC}$ & 55151,51 \\
\hline
\end{tabular}

Pozn.: ***p $\leq 0,001 * * \mathrm{p} \leq 0,010 * \mathrm{p} \leq 0,050+\mathrm{p} \leq 0,1$.

Ze statistik v tabulce 7 lze vypočítat, o kolik vyšší riziko mají hypogamní kohabitace v porovnání s hypergamními - vydělením čísel ve třetím řádku čísly $\mathrm{v}$ druhém řádku. Hypogamní soužití měla oproti těm hypergamním vyšší riziko v každém období (pouze 
v období 1990-2002 byl rozdíl nevýznamný na hladině 0,1). Mezi lety 1978 a 1989 měla hypogamní soužití o $148 \%(\mathrm{p}<0,1)$ vyšší riziko než hypergamní, mezi lety 1990 a 2002 to bylo $83 \%(\mathrm{p}>0,1)$ a v letech 2003-2011 $163 \%(\mathrm{p}<0,05)$.

Tabulka 7: Poměry rizik nesezdaných soužití podle relativního vzdělání partnerů a roku jejich vzniku. GGS 1. Nesezdaná soužití respondentů do 45 let. $\mathrm{N}=6660$

\begin{tabular}{|l|c|c|c|}
\hline & $\mathbf{1 9 7 8 - 1 9 8 9}$ & $\mathbf{1 9 9 0 - 2 0 0 2}$ & $\mathbf{2 0 0 3 - 2 0 1 1}$ \\
\hline Homogamie & 1,00 & 1,00 & 1,00 \\
\hline Hypergamie & 0,69 & $0,63+$ & $0,63+$ \\
\hline Hypogamie & $1,71^{*}$ & 1,15 & $1,66^{*}$ \\
\hline
\end{tabular}

Pozn.: ***p $\leq 0,001 * * p \leq 0,010 * p \leq 0,050+p \leq 0,1$.

\section{Závěrečná diskuse}

Výsledky analýzy v nesouladu s první hypotézou ukázaly, že heterogamní nesezdaná soužití jako celek neměla ve všech zemích významně nižší riziko vstupu do manželství než homogamní. Zatímco hypogamie (žena má vyšší vzdělání než muž) nebyla v žádné zemi významně asociovaná s tranzicí do manželství, hypergamie (muž má vy̌šší vzdělání než žena) riziko tranzice redukovala, v Polsku o $40 \%$ a v Česku o $54 \%$. Oproti předpokladům druhé hypotézy se ukázalo, že hypogamní kohabitace měly v Polsku a v Česku vyšší riziko manželství než kohabitace hypergamní. Analýza podpořila třetí hypotézu: asociace byla nejslabší v Rakousku, kde mají nesezdaná soužití blíže k manželství než v Polsku a Česku (Heuveline a Timberlake 2004). Asociace nezávisela na tom, kdy kohabitace vznikly - poslední hypotézu tedy analýza nepodpořila.

Výsledky ukázaly, že selektivní proces ve vybraných třech zemích fungoval jinak, než se předpokládalo. Zatímco v USA podle Schwartz (2010) vedly homogamní kohabitace $\mathrm{k}$ manželství častěji než ty heterogamní, $\mathrm{v}$ analyzovaných zemích nebyl efekt vzdělanostní heterogamie tak jednoznačný. Schwartz (2010) totiž ve své studii nerozlišovala kohabitace podle toho, kdo má vyšší vzdělání. Výsledky této analýzy přitom ukázaly, že hypergamie a hypogamie na riziko tranzice do manželství působily odlišně. V zemích, kde selektivní proces fungoval, vedly nejčastěji k manželství kohabitace, v nichž měla vy̌̌ší vzdělání žena. Možným důvodem tohoto překvapivého výsledku je poměr moci ve vztahu. Jelikož ženy chtějí manželství více než muži, zčásti nejspíš i kvůli požadavkům společnosti (Blakemore et al. 2005), pro ženu s vyšším vzděláním může být jednodušší si vstup do manželství prosadit - i proto, že je pro ni jednodušší ze vztahu odejít než pro méně vzdělanou ženu (Kreager et al. 2013; Levinger 1976). To, že měla hypogamní soužití vyšší pravděpodobnost manželství, napovídá, že vyšší socioekonomický status žen nemusí být pro manželství překážkou. Je ale třeba upozornit, že data neobsahovala další měřítka socioekonomického statusu, která v tranzici do manželství mohou hrát roli. Pokud má žena vyšší vzdělání než muž, nemusí to znamenat, že má také vyšší př́ijem, jelikož v př́ijmech existuje genderový rozdíl (Redmond a Mcguinness 2018). 
To, že v některých zemích kohabitace se vzdělanější ženou vedly častěji k manželství než ty se vzdělanějším mužem, může mít důsledky i pro další demografické chování, například sňatečnost. Jak ukázali např́iklad De Hauw et al. (2017), kvưli převrácení genderového rozdílu ve vzdělání a rostoucímu podílu žen s vysokoškolským vzděláním přibývá manželství i kohabitací, ve kterých žena svým vzděláním převyšuje muže. Pokud se lidé v hypogamních kohabitacích častěji berou, mohla by jejich vyšší pravděpodobnost manželství společně s rostoucím podílem hypogamních kohabitací vést ke zpomalení nebo obrácení trendu klesající sňatečnosti, ke které v zemích střední a východní Evropy docházelo od devadesátých let minulého století (Sobotka a Toulemon 2008).

Analýza byla limitována množstvím informací, které respondenti poskytovali o svých vztazích. V datech např́klad neuváděli, jaké měli vzdělání v době vztahu, a proto byla analýza omezena jen na ty vztahy, v nichž měli stejné vzdělání jako v době sběru dat. Kvůli tomu mohl být podhodnocený poměr respondentů s vyšším vzděláním ve vzorku, protože vyloučené vztahy častěji zahrnovaly respondenty, kteří měli v době sběru dat terciární vzdělání. Analytický vzorek obsahoval dohromady 6660 nesezdaných soužití, která vznikla mezi lety 1978 a 2011, ale protože se sběr dat konal v každé zemi v jiném období, stáří kohabitací uváděných v partnerských historiích se napříč zeměmi lišilo. Výsledky analýzy také nemusí odrážet nejnovější trendy partnerského chování, které se od doby sběru dat mohlo proměnit.

Přes diskutovaná omezení přinesla studie zajímavé výsledky. Nejdůležitějším zjištěním je to, že selektivní přechod do manželství není univerzálním procesem a závisí na významu kohabitací v dané zemi. Zatímco v rakouských kohabitacích při tranzici do manželství nezáleželo na relativním vzdělání partnerů, v Polsku a v Česku při přechodu do manželství hrálo roli. Výsledky naznačují, že přestože už difúzní proces (Nazio 2008) rozšíril kohabitace do všech evropských krajin, ve dvou ze tří zkoumaných zemí lidé ještě na počátku 21. století připisovali kohabitacím rozdílné významy než manželství, jelikož mezi těmito svazky probíhal selektivní proces. Jak tvrdí Di Giulio a Rosina (2007), difúzi nesezdaných soužití ovlivňuje škála faktorů, např́klad sociální a kulturní kontext, postoje mladých dospělých a jejich rodičů, ale také politiky, které bud’to ulehčují, nebo ztěžují formování prvních partnerských svazků. Proto je možné, že některé země nikdy nedojdou do stavu, kdy jsou kohabitace alternativou manželství (Di Giulio et al. 2019).

\section{Literatura}

BECKER, Gary S. 1985. „Human Capital, Effort, and the Sexual Division of Labor.“ Journal of Labor Economics 3(1): 33-58.

BELLANI, Daniela, Gøsta ESPING-ANDERSEN a Lesia NEDOLUZHKO. 2017. „Never Partnered: A Multilevel Analysis of Lifelong Singlehood.“ Demographic Research 37: 53-100.

BERGHAMMER, Caroline, Katrin FLIEGENSCHNEE a Eva-Maria SCHMIDT. 2014. „Cohabitation and Marriage in Austria: Assessing the Individualization Thesis across the Life Course." Demographic Research 31: 1137-1166.

BILLARI, Francesco C. a Aart C. LIEFBROER. 2016. „Why Still Marry? The Role of Feelings in the Persistence of Marriage as an Institution.“ The British Journal of Sociology 67(3): 516-540.

BLACKWELL, Debra L. a Daniel T. LICHTER. 2000. „Mate Selection Among Married and Cohabiting Couples.“ Journal of Family Issues 21(3): 275-302. 
BLACKWELL, Debra L. a Daniel T. LICHTER. 2004. „Homogamy Among Dating, Cohabiting, and Married Couples.“ The Sociological Quarterly 45(4): 719-737.

BLAKEMORE, Judith E. Owen, Carol A. LAWTON a Lesa Rae VARTANIAN. 2005. „I Can’t Wait to Get Married: Gender Differences in Drive to Marry.“ Sex Roles 53(5-6): 327-335.

BLOSSFELD, Hans-Peter. 2009. „Educational Assortative Marriage in Comparative Perspective.“ Annual Review of Sociology 35(1): 513-530.

DE HAUW, Yolien, André GROW a Jan VAN BAVEL. 2017. „The Reversed Gender Gap in Education and Assortative Mating in Europe.“ European Journal of Population 33(4): 445-474.

DI GIULIO, Paola a Alessandro ROSINA. 2007. „Intergenerational Family Ties and the Diffusion of Cohabitation in Italy.“ Demographic Research 16: 441-468.

DI GIULIO, Paola, Roberto IMPICCIATORE a Maria SIRONI. 2019. „, The Changing Pattern of Cohabitation: A Sequence Analysis Approach.“ Demographic Research 40: 1211-1248.

DOMAŃSKI, Henryk a Dariusz PRZYBYSZ. 2007. „Educational Homogamy in 22 European Countries.“ European Societies 9(4): 495-526.

DOMÍNGUEZ-FOLGUERAS, Marta. 2013. „Is Cohabitation More Egalitarian? The Division of Household Labor in Five European Countries.“ Journal of Family Issues 34(12): 1623-46.

ESTEVE, Albert, Christine R. SCHWARTZ, Jan Van BAVEL, Iñaki PERMANYER, Martin KLESMENT a Joan GARCÍA-ROMÁN. 2016. „The End of Hypergamy: Global Trends and Implications: The End of Hypergamy: Global Trends and Implications." Population and Development Review 42(4): 615-625.

GAUTHIER, Anne H., Susana Laia Farinha CABAÇO a Tom EMERY. 2018. „Generations and Gender Survey Study Profile.“ Longitudinal and Life Course Studies 9(4): 456-465.

GENERATIONS AND GENDER PROGRAMME. 2019. Generations and Gender Survey (GGS) - Wave 1.

HAMPLOVÁ, Dana. 2002. „Marriage and Cohabitation: Qualitative Differences in Partnership Arrangements.“ Czech Sociological Review 38(6): 771-788.

HAMPLOVÁ, Dana. 2009. „Educational Homogamy Among Married and Unmarried Couples in Europe: Does Context Matter?“ Journal of Family Issues 30(1): 28-52.

HAMPLOVÁ, Dana. 2015. „Nesezdané soužití - společné bydlení bez společné peněženky?“ Czech Sociological Review 51(2): 261-278.

HAMPLOVÁ, Dana a Simona PIKÁLKOVÁ. 2002. „Manželství, nesezdaná soužití a partnerský vztah.“ Pp. 127-147 in Zdenka MANSFELDOVÁ a Milan TUČEK (eds.). Současná česká společnost. Praha: Sociologický ústav AV ČR.

HAMPLOVÁ, Dana a Céline LE BOURDAIS. 2008. „Educational Homogamy of Married and Unmarried Couples in English and French Canada.“ Canadian Journal of Sociology 33(4): 845-872.

HEUVELINE, Patrick a Jeffrey M. TIMBERLAKE. 2004. „The Role of Cohabitation in Family Formation: The United States in Comparative Perspective." Journal of Marriage and Family 66(5): $1214-1230$.

CHALOUPKOVÁ, Jana. 2011. „Nejdřive dítě, potom svatba? Rodinné dráhy neprovdaných matek.“ Gender, rovné přiležitosti, výzkum 12(2): 30-39.

CHERLIN, Andrew J. 2020. „Degrees of Change: An Assessment of the Deinstitutionalization of Marriage Thesis.“ Journal of Marriage and Family 82(1): 62-80.

CHUDNOVSKAYA, Margarita a Ridhi KASHYAP. 2020. „Is the End of Educational Hypergamy the End of Status Hypergamy? Evidence from Sweden." European Sociological Review 36(3): $351-365$.

KALMIJN, Matthijs. 2011. „The Influence of Men's Income and Employment on Marriage and Cohabitation: Testing Oppenheimer's Theory in Europe.“ European Journal of Population 27(3): 269-293.

KALMIJN, Matthijs. 2013. „The Educational Gradient in Marriage: A Comparison of 25 European Countries.“ Demography 50(4): 1499-1520. 
KATRŇÁK, Tomáš. 2008a. Spřiznění volbou: Homogamie a heterogamie manželských párů v České republice. Brno: Masarykova univerzita.

KATRŇÁK, Tomáš. 2008b. „Educational Assortative Mating in the Czech Republic, Slovakia and Hungary between 1976 and 2003.“ Sociologia 40(3): 236-257.

KATRŇÁK, Tomáš, Martin KREIDL a Laura FÓNADOVÁ. 2006. „Trends in Educational Assortative Mating in Central Europe: The Czech Republic, Slovakia, Poland, and Hungary, 1988-2000.“ European Sociological Review 22(3): 309-322.

KIERNAN, Kathleen. 2002. „Cohabitation in Western Europe: Trends, Issues, and Implications.“ Pp. 3-31 in Alan BOOTH a Ann C. CROUTER (eds.). Just Living Together: Implications of Cohabitation on Families, Children, and Social Policy. Mahwah, NJ: L. Erlbaum Associates.

KLÍMOVÁ CHALOUPKOVÁ, Jana. 2018. „The Division of Housework in Czech Married and Cohabiting Couples: Does the Type of Union Have an Effect and What's Considered Fair?" Czech Sociological Review 54(4): 593-624.

KREAGER, Derek A., Richard B. FELSON, Cody WARNER a Marin R. WENGER. 2013. „Women's Education, Marital Violence, and Divorce: A Social Exchange Perspective. “Journal of Marriage and Family 75(3): 565-581.

KREIDL, Martin. 2010. „Dochází v ČR ke konvergenci hodnotového profilu lidí žijících v manželství a nesezdaném soužití?“ Sociální studia 7(4): 85-100.

KREIDL, Martin a Martina ŠTÍPKOVÁ. 2012. „Výskyt a načasování nesezdaných soužití v současné ČR.“ Demografie 54(2): 120-137.

LEVINGER, George. 1976. „A Social Psychological Perspective on Marital Dissolution.“ Journal of Social Issues 32(1): 21-47.

MÄENPÄÄ, Elina. 2015. „Socio-Economic Homogamy and its Effects on the Stability of Cohabiting Unions." Finnish Yearbook of Population Research 50.

MARE, Robert D. 1991. „Five Decades of Educational Assortative Mating.“ American Sociological Review 56(1): 15-32.

MATYSIAK, Anna. 2009. „Is Poland Really ,Immune“ to the Spread of Cohabitation?“ Demographic Research 21: 215-234.

MYNARSKA, Monika a Laura BERNARDI. 2007. „Meanings and Attitudes Attached to Cohabitation in Poland: Qualitative Analyses of the Slow Diffusion of Cohabitation among the Young Generation." Demographic Research 16: 519-554.

MYNARSKA, Monika a Anna MATYSIAK. 2010. „Diffusion of Cohabitation in Poland.“ Studia Demograficzne 157-158 (1-2): 11-26.

NAZIO, Tiziana. 2008. Cohabitation, Family and Society. New York: Routledge.

PERELLI-HARRIS, Brienna a Laura BERNARDI. 2015. „Exploring Social Norms around Cohabitation: The Life Course, Individualization, and Culture: Introduction to Special Collection: ,Focus on Partnerships: Discourses on Cohabitation and Marriage throughout Europe and Australia'،“ Demographic Research 33: 701-732.

POTARCA, Gina. 2017. „Does the Internet Affect Assortative Mating? Evidence from the U.S. and Germany.“ Social Science Research 61: 278-297.

QIAN, Yue. 2017. „Gender Asymmetry in Educational and Income Assortative Marriage: Educational and Income Assortative Marriage.“ Journal of Marriage and Family 79(2): 318-336.

REDMOND, Paul a Seamus MCGUINNESS. 2018. „The Gender Wage Gap in Europe: Job Preferences, Gender Convergence and Distributional Effects." Oxford Bulletin of Economics and Statistics 81(3): 564-587.

REZNIK, Oleksandr. 2014. „Economic Factors of Marriage and Cohabitation in European Countries.“ Economics \& Sociology 7(1): 131-141. 
SASSLER, Sharon a Daniel T. LICHTER. 2020. „Cohabitation and Marriage: Complexity and Diversity in Union-Formation Patterns." Journal of Marriage and Family 82(1): 35-61.

SCHWARTZ, Christine R. 2010. „Pathways to Educational Homogamy in Marital and Cohabiting Unions.“ Demography 47(3): 735-753.

SCHWARTZ, Christine R. a Hongyun HAN. 2014. „The Reversal of the Gender Gap in Education and Trends in Marital Dissolution.“ American Sociological Review 79(4): 605-629.

SOBOTKA, Tomáš a Laurent TOULEMON. 2008. „Overview Chapter 4: Changing Family and Partnership Behaviour.“ Demographic Research 19: 85-138.

SULLIVAN, Oriel, Jonathan GERSHUNY a John P. ROBINSON. 2018. „Stalled or Uneven Gender Revolution? A Long-Term Processual Framework for Understanding Why Change Is Slow: Stalled or Uneven Gender Revolution?" Journal of Family Theory \& Review 10(1): 263-279.

STATACORP. 2013. Stata Survival Analysis and Epidemiological Tables Reference Manual. College Station, TX: Stata Press. Cit. 23. června 2020 (https://www.stata.com/manuals13/st.pdf).

STATACORP. 2019. Stata Statistical Software: Release 16. College Station, TX: StataCorp LLC.

ŠETINOVÁ, Markéta a Jana KLÍMOVÁ CHALOUPKOVÁ. 2019. „Role kognitivních schopností ve výběrovém párování: partnerské preference mladých lidí.“ Sociologický časopis 55(2): 161-188.

ŠŤASTNÁ, Anna. 2011. „Analýza historie událostí (event history analýza) - možnosti a základní principy při studiu životních drah.“ Data a výzkum - SDA Info 5(1): 59-83.

ŠŤASTNÁ, Anna a Jana PALONCYOVÁ. 2011. „První partnerská soužití českých žen a mužů a rostoucí význam kohabitací." Gender, rovné př́ležitosti, výzkum 12(2): 16-29.

THORNTON, Arland, William G. AXINN a Yu XIE. 2007. Marriage and Cohabitation. Chicago: University of Chicago Press.

TOMÁŠEK, Marcel. 2006. „Singles a jejich vztahy; kvalitativní pohled na nesezdané a nekohabitující jednotlivce v České republice.“ Czech Sociological Review 42(1): 81-106.

VAN BAVEL, Jan, Christine R. SCHWARTZ a Albert ESTEVE. 2018. „The Reversal of the Gender Gap in Education and Its Consequences for Family Life." Annual Review of Sociology 44: 341-356.

VIKAT, Andres, Zsolt SPÉDER, Gijs BEETS, Francesco BILLARI, Christoph BÜHLER, Aline DESESQUELLES, Tineke FOKKEMA, Jan M. HOEM, Alphonse MACDONALD, Gerda NEYER, Ariane PAILHÉ, Antonella PINNELLI a Anne SOLAZ. 2007. „Generations and Gender Survey (GGS): Towards a Better Understanding of Relationships and Processes in the Life Course.“ Demographic Research 17: 389-440.

VÍTEČKOVÁ, Miluše a Lucie JÍLKOVÁ. 2011. „Nesezdané soužití - otázka pojmenování.“ Lidé města 13(1): 73-86.

WALTERS, Stephen J. 2012. „Analyzing Time to Event Outcomes with a Cox Regression Model.“ Wiley Interdisciplinary Reviews: Computational Statistics 4(3): 310-315.

ZENTNER, Marcel a Klaudia MITURA. 2012. „Stepping Out of the Caveman's Shadow: Nations' Gender Gap Predicts Degree of Sex Differentiation in Mate Preferences." Psychological Science 23(10): 1176-1185.

ZENTNER, Marcel a Alice H. EAGLY. 2015. „A Sociocultural Framework for Understanding Partner Preferences of Women and Men: Integration of Concepts and Evidence." European Review of Social Psychology 26(1): 328-373.

\section{Autorka}

Dominika Sladká je doktorská studentka sociologie se zaměřním na populační studia na Fakultě sociálních studií Masarykovy univerzity v Brně. Zabývá se sociologií rodiny, především tématy partnerských vztahů, nesezdaných soužití a manželství.

Kontakt:d.sladka@mail.muni.cz 